ISSN : 2580-3220, E-ISSN : 2580-4588

J. Mandiri., Vol. 4, No. 2, Desember 2020 (114 - 122)

(C)2018 Lembaga Kajian Demokrasi

dan Pemberdayaan Masyarakat (LKD-PM)

DOI : https://doi.org/10.33753/mandiri.v4i2.130

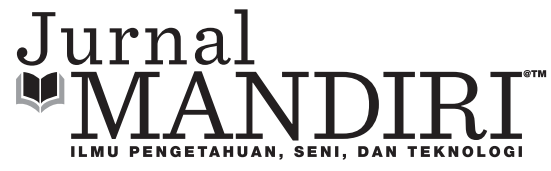

\title{
Analisis Faktor-Faktor Kinerja UMKM di Kecamatan Bogor Utara, Kota Bogor
}

\author{
Lina Aryani \\ Fakultas Ekonomi dan Bisnis, Universitas Pembangunan Nasional “Veteran” Jakarta \\ lina.aryani59@gmail.com \\ Desmintari \\ Fakultas Ekonomi dan Bisnis, Universitas Pembangunan Nasional “Veteran” Jakarta \\ desmintari@yahoo.com \\ Pusporini \\ Fakultas Ekonomi dan Bisnis, Universitas Pembangunan Nasional “Veteran” Jakarta \\ pusporini61@yahoo.com
}

\begin{abstract}
Abstrak
Tujuan penelitian ini adalah untuk mengidentifikasi dan mengetahui faktor internal, eksternal, dan kewirausahaan yang mempengaruhi kinerja UMKM Kuliner dan Fashion di Kecamatan Bogor Utara. Anggota populasi dari penelitian ini adalah UMKM kuliner dan fashion. Metode penelitian menggunakan metode Non Probability sampling. Sumber data yang digunakan adalah data primer yang diperoleh dengan menggunakan daftar pertanyaan (kuesioner) dengan sampel yang digunakan sebanyak 100 UMKM kuliner dan fashion di Bogor Utara. Analisis data dalam penelitian ini digunakan dua pendekatan, yaitu analisis deskriptif dan analisis PLS (Partial Least Square). Hasil penelitian menunjukkan besarnya $R$ Square $\left(R^{2}\right)$ Kinerja UMKM adalah sebesar 0,506. Artinya adalah faktor internal, faktor eksternal, dan faktor kewirausahaan memberikan kontribusi pengaruh sebesar 50,6\% terhadap kinerja UMKM. Sedangkan sisanya sebesar 49,4\% dipengaruhi oleh faktor lain. Simpulan penelitian ini adalah faktor eksternal, faktor internal, dan kewirausahaan berpengaruh dan signifikan terhadap Kinerja UMKM. Berdasarkan hasil uji t-statistic, diperoleh hasil bahwa faktor eskternal merupakan faktor yang paling berpengaruh dan signifikan terhadap kinerja UMKM.
\end{abstract}

Kata Kunci : Faktor Eksternal, Faktor Internal, Kewirausahaan, Kinerja UMKM

\begin{abstract}
The purpose of this study is to identify and determine the internal, external, and entrepreneurial factors that affect the performance of Culinary and Fashion MSMEs in North Bogor District. The population members of this study were culinary and fashion MSMEs. The research method uses the Non-Probability sampling method. The data source used is primary data obtained by using a list of questions (questionnaire) with a sample of 100 culinary and fashion MSMEs in North Bogor. Data analysis in this study used two approaches, namely descriptive analysis and PLS (Partial Least Square) analysis. The results showed the amount of $R$ Square $\left(R^{2}\right)$ MSME performance was 0.506. This means that internal factors, external factors, and entrepreneurial factors contribute $50.6 \%$ to the performance of MSMEs. While the remaining $49.4 \%$ is influenced by other factors. The conclusion were external factors, internal factors, and entrepreneurship had a significant effect on the performance of MSMEs.
\end{abstract}

Keywords : External Factor, Internal Factor, Entrepreneurship, MSME Performance 


\section{PENDAHULUAN}

Keberadaan Usaha Mikro, Kecil, dan Menengah (UMKM) di negara berkembang dapat dikatakan sebagai tulang punggung perekonomian. UMKM merupakan tulang punggung sistem ekonomi kerakyatan untuk mengurangi masalah kesenjangan ekonomi, pengentasan kemiskinan, dan peningkatan penyerapan tenaga kerja. UMKM mampu memperluas basis ekonomi dan dapat memberikan konstribusi yang signifikan dalam mempercepat perubahan struktural, yaitu meningkatnya perekonomian daerah dan ketahanan ekonomi nasional.

Bogor adalah salah satu kota yang memiliki daya tarik pariwisata di Jawa Barat. Menurut Data Badan Pusat Statistik Kota Bogor, jumlah wisatawan nusantara berkunjung ke Kota Bogor pada tahun 2015 mencapai 4.783 .848 turis, meningkat dibandingkan dengan tahun 2014 yang mencapai 4.348.593 turis.

Kota Bogor menawarkan berbagai produk olahan pangan dan produk lainnya yang inovatif dan kreatif. Produk-produk tersebut merupakan produk dari UMKM lokal. Jumlah UMKM yang beroperasi di Kota Bogor mencapai 29.406 unit. Kecamatan Bogor Utara merupakan salah satu kawasan yang memiliki banyak UMKM yakni mencapai 2.557 unit.

Untuk mempertahankan eksistensi dan kualitasnya, UMKM harus mampu memetakan faktor apa saja yang berpengaruh terhadap kinerja UMKM tersebut. Hal ini bertujuan agar UMKM mengetahui potensi dan aspek-aspek yang perlu diperbaiki sehingga dapat menjadi acuan dalam pengambilan keputusan dan strategi bisnis mereka untuk memperoleh keuntungan dan meningkatkan kinerja UMKM.

Banyak faktor yang mempengaruhi prestasi UMKM, di antaranya adalah pengaruh faktor internal dan eksternal. Faktor internal berasal dari dalam UMKM itu sendiri sedangkan faktor eksternal berasal dari luar UMKM. Menurut Haeruman (2000) tantangan internal bagi UMKM terutama dalam pengembangannya mencakup aspek yang luas yakni peningkatan kualitas sumber daya manusia, kemampuan manajemen, organisasi dan teknologi, kompetensi kewirausahaan, akses yang lebih luas terhadap permodalan, informasi pasar yang transparan, faktor input produksilainnya, daniklim usaha yang sehat yang mendukung inovasi, kewirausahaan, dan praktik bisnis serta persaingan yang sehat.

Said (2004) menjelaskan dengan adanya peningkatan nilai kewirausahaan, kemampuan pemasaran, teknologi, dan pengelolaan keuangan, maka tentunya prestasiusahakecilakanmeningkat. Faktor eksternal meliputi jaringan sosial, legalitas, dukungan pemerintah, pembinaan, teknologi, dan akses kepada informasi (Jauch dan Glueck, 2000). Keberhasilan akan tercapai jika adanya kesesuaian antara faktor internal dengan faktor eksternal melalui penerapan cara yang tepat.

UMKM harus mampu mengelola faktor internal seperti sumber daya manusia, pemasaran, keuangan, dan operasional serta mengintegrasikan seluruh faktor tersebut agar mampu bersinergi secara harmonis dan selaras sehingga dapat menunjang usaha. UMKM juga harus memperhatikan faktor-faktor eksternal seperti kebijakan pemerintah, kondisi perekonomian, sosial budaya, teknologi, dinamika politik, regulasi, dan perkembangan industri karena faktor ini tidak dapat diatur sendiri oleh UMKM tersebut. UMKM harus mampu menyesuaikan diri dengan faktorfaktor eksternal tersebut agar dapat menjadi peluang bagi UMKM untuk mengembangkan usahanya. Selain kedua faktor tersebut masih ada faktor kewirausahaan yaitu memiliki jiwa wirausaha, kualitas dalam bekerja, percaya diri, dan dapat bekerja sama.

Penelitian juga dilakukan oleh Subroto, et al (2016) yang meneliti Faktor-Faktor Yang Mempengaruhi Kinerja Usaha Mikro Kecil Dan Menengah (UMKM) Kabupaten Brebes. Hasil penelitian adalah bahwa kinerja UMKM dipengaruhi oleh faktor external dan internal masih dapat terus ditingkatkan dengan meningkatkan keempat faktor internal yaitu SDM, keuangan, produksi, dan pemasaran. Pemilik UMKM dapat melakukan inovasi pelatihan SDM meskipun kualitas awal ketika karyawan bekerja di perusahaan masih rendah. Faktor keuangan dapat ditingkatkan dengan cara menjalin kemitraan dengan instansi pemerintah dan lembaga keuangan 
sehingga akan memperoleh tambahan modal tanpa persyaratan yang memberatkan UMKM. Peningkatan faktor produksi sangat bergantung pada peningkatan kemampuan dan kompetensi SDM.

Penelitian Kristiningsih dan Adrianto Trimarjono (2014) tentang Analisis Faktor-Faktor yang Mempengaruhi Perkembangan Usaha Kecil Menengah (Studi Kasus Pada UKM Di Wilayah Surabaya), menyimpulkan bahwa pengelolaan keuangan berdampak pada perkembagan UKM. Sedangkan aspek sumber daya manusia, produksi, dan pemasaran tidak berdampak pada perkembangan UKM.

Kemudian penelitian yang dilakukan oleh Ratnawati dan Hikmah (2020) yang meneliti Faktor-Faktor Yang Mempengaruhi Kinerja UKM (Studi Kasus UKM Di Kabupaten dan Kota Semarang). Hasil penelitian menunjukkan kebutuhan akan prestasi, kebutuhan akan afiliasi, dan kebutuhan akan otonomi secara simutan dan signifikan berpengaruh terhadap kinerja. Selanjutnya pemasaran, teknologi, akses kepada modal, pengaruh akses kepada informasi, jaringan sosial, legalitas, rencana bisnis, kesiapan berwirausaha, dukungan pemerintah secara simultan dan signifikan berpengaruh terhadap kinerja.

Berdasarkan uraian latar belakang penelitian di atas, penulis akan melakukan penelitian yang bertujuan untuk mengetahui apakah faktor eksternal, faktor internal, dan faktor kewirausahaan mempengaruhi kinerja UMKM di Kecamatan Bogor Utara.

\section{METODE}

Data dalam penelitian ini adalah data primer yang diperoleh dari responden. Sampel yang digunakan sebanyak 100 UMKM Kuliner dan Fashion di Kecamatan Bogor Utara dengan metode Non Probability Sampling, di mana tidak semua populasi mempunyai kesempatan yang sama untuk menjadi sampel (calon responden). Penentuan ukuran sampel sebagaimana yang dikemukakan oleh Ferdinand (2011, hlm. 217), bahwa ukuran sampel yang layak atau memadai yaitu antara 30 sampai 500. Kemudian menurut
Noor (2014, hlm. 151), ukuran sampel yang layak dalam penggunaan aplikasi Partial Least Square adalah minimal 30-50 atau sampel besar di atas 200.

Instrumen utama yang digunakan dalam penelitian ini adalah berupa kuesioner yang dibagikan kepada responden yang dipandu melalui wawancara langsung. Proses wawancara untuk pengisian kuesioner dilakukan kepada UMKM yang sudah dipilih atau ditentukan oleh penulis. Analisis kuantitatif akan menggunakan beberapa model analisis ekonomi dan matematik yaitu analisis deskriptif dan analisis PLS (Partial Least Square).

Analisis PLS merupakan alternatif yang baik untuk metode regresi berganda karena bersifat robust atau kebal, artinya parameter model tidak banyak berubah ketika sampel baru diambil dari total populasi. PLS juga merupakan suatu metode analisis yang tidak didasarkan pada banyak asumsi atau syarat seperti uji normalitas dan multikolinearitas. Keunggulan metode PLS adalah data tidak harus berdistribusi normal, multi-variate, dan ukuran sampel tidak harus besar.

Hipotesis pada penelitian ini adalah:

1. Diduga ada pengaruh signifikan variabel faktor eksternal terhadap kinerja UMKM.

2. Diduga ada pengaruh signifikan variabel faktor internal terhadap kinerja UMKM.

3. Diduga ada pengaruh signifikan variabel faktor kewirausahaan terhadap kinerja UMKM.

\section{HASIL dan PEMBAHASAN}

Hasil

\section{Analisis Identitas Konsumen}

Berdasarkan tabel 1, responden yang kepemilikan usahanya merupakan milik sendiri jumlahnya adalah 54 responden (54\%). Artinya yang mendominasi sebagian besar responden merupakan UMKM yang memiliki kepemilikan usaha sendiri. 


\begin{tabular}{|c|c|c|}
\hline \multicolumn{3}{|c|}{ Tabel 1. Profil Kepemilikan Usaha Responden } \\
\hline Kepemilikan Usaha & Jumlah & Persentase (\%) \\
\hline Milik Sendiri & 54 & 54 \\
\hline Usaha Bersama & 26 & 26 \\
\hline Usaha Keluarga & 20 & 20 \\
\hline
\end{tabular}

Berdasarkan tabel 2, responden yang memiliki modal usaha di atas 100 juta rupiah jumlahnya adalah 52 responden (52\%). Artinya sebagian besar responden merupakan UMKM yang memiliki modal usaha di atas 100 juta rupiah dengan 52 responden (52\%).

\begin{tabular}{|c|c|c|}
\hline \multicolumn{3}{|c|}{ Tabel 2. Profil Modal Usaha Responden } \\
\hline Modal Usaha (Rp) & Jumlah & Persentase (\%) \\
\hline $50-75$ juta & 28 & 28 \\
\hline $75-100$ juta & 20 & 20 \\
\hline$>100$ juta & 52 & 52 \\
\hline
\end{tabular}

Berdasarkan tabel 3, sebagian besar responden merupakan UMKM yang memiliki pendapatan usaha di antara 20 juta-30 juta rupiah per bulan dengan 38 responden (38\%).

\begin{tabular}{|c|c|c|}
\hline \multicolumn{2}{|c|}{ Tabel 3. Profil Pendapatan Usaha Responden } \\
\hline $\begin{array}{c}\text { Pendapatan Usaha } \\
\text { (Rp per bulan) }\end{array}$ & Jumlah & Persentase (\%) \\
\hline$<20$ juta & 27 & 27 \\
\hline 20 juta - 30 juta & 38 & 38 \\
\hline$>30$ juta & 35 & 35 \\
\hline
\end{tabular}

\section{Uji Validitas Dan Reliabilitas PLS}

Dalam penelitian ini untuk menguji validitas dan reliabilitas data yang diolah dengan menggunakan dua model, yaitu model pengukuran (outer model) dan model struktural (inner model).

\section{Model Pengukuran (Outer Model)}

Langkah pertama yang dilakukan adalah menguji apakah model sudah memenuhi convergent validity yaitu apakah loading faktor indikator untuk masing-masing konstruk sudah memenuhi convergent validity. Hasil uji validitas diagram jalur awal dengan Smart-PLS 3.0 menunjukkan diagram jalur yang terbentuk dapat dilihat pada Gambar 1.

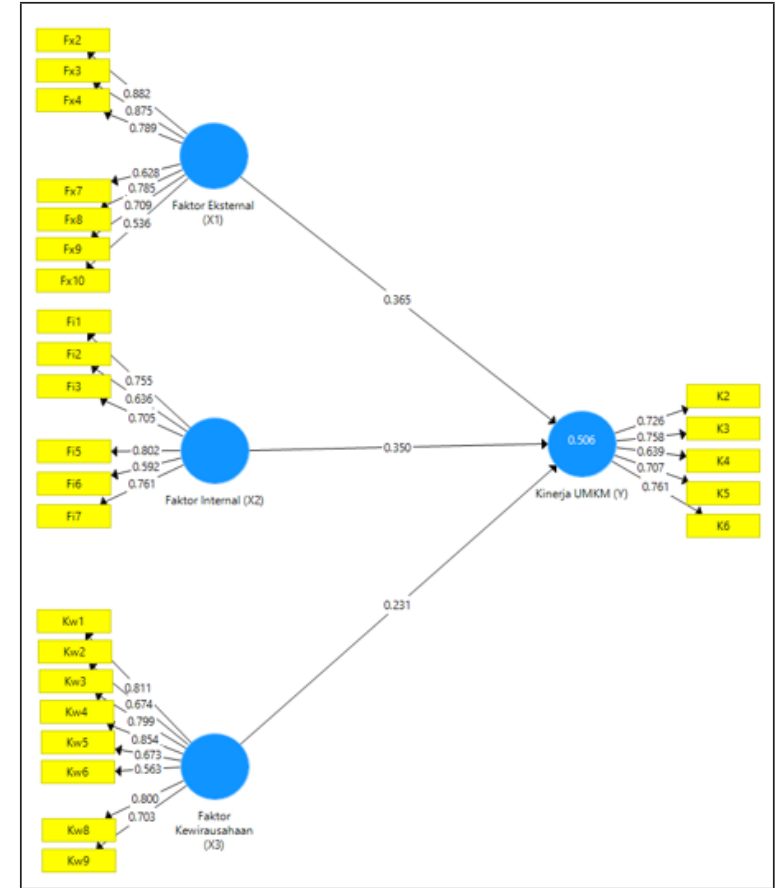

Gambar 1. Nilai Loading Faktor Menggunakan Diagram Jalur PLS

Indikator dapat dianggap valid jika ukuran refleksi individual dikatakan tinggi (berkorelasi di atas 0.7 ) dengan konstruk yang ingin diukur. Namun pada riset tahap pengembangan, skala loading 0.5 sampai dengan 0.6 masih dapat dikatakan memadai sebagai kriteria terpenuhinya validitas konvergen (Ghozali, 2014 hlm. 39).

Hasilnya, dapat disimpulkan bahwa semua indikator individu pada setiap variabel yang digunakan dalam penelitian ini yaitu Faktor Internal, Faktor Eksternal, Kewirausahaan, dan Kinerja UMKM telah memenuhi syarat karena semua nilai kolerasi berada angka di atas (>) 0.5.

\section{Uji Validitas Konverengen}

Hasil output software Smart PLS 3.0 didapat nilai loading faktor masing-masing indikator masing-masing konstruk sebagai berikut:

\begin{tabular}{|c|c|c|c|c|}
\hline \multicolumn{5}{|c|}{ Tabel 4. Outer Loading Faktor } \\
\hline & Fx & Fi & Kw & K \\
\hline$F \times 2$ & 0.882 & & & \\
\hline$F \times 3$ & 0.875 & & & \\
\hline$F \times 4$ & 0.789 & & & \\
\hline$F \times 7$ & 0.628 & & & \\
\hline$F \times 8$ & 0.785 & & & \\
\hline$F \times 9$ & 0.709 & & & \\
\hline$F \times 10$ & 0.536 & & & \\
\hline
\end{tabular}




\begin{tabular}{|c|l|l|l|l|}
\hline Fi1 & & 0.755 & & \\
\hline Fi2 & & 0.636 & & \\
\hline Fi3 & & 0.705 & & \\
\hline Fi5 & & 0.802 & & \\
\hline Fi6 & & 0.592 & & \\
\hline Fi7 & & 0.761 & & \\
\hline Kw1 & & & 0.811 & \\
\hline Kw2 & & & 0.674 & \\
\hline Kw3 & & & 0.799 & \\
\hline Kw4 & & & 0.854 & \\
\hline Kw5 & & & 0.673 & \\
\hline Kw6 & & & 0.563 & \\
\hline Kw8 & & & 0.800 & \\
\hline Kw9 & & & 0.703 & \\
\hline K2 & & & & 0.726 \\
\hline K3 & & & & 0.758 \\
\hline K4 & & & & 0.639 \\
\hline K5 & & & & 0.707 \\
\hline K6 & & & & 0.761 \\
\hline
\end{tabular}

Pada tabel di atas menunjukkan bahwa semua nilai loading faktor di atas 0,5 dan nilai paling kecil adalah sebesar 0.536 untuk indikator Fx10. Berarti indikator yang dipergunakan dalam penelitian ini adalah valid atau telah memenuhi convergent validity.

\section{Uji Validitas Diskriminan}

Metode untuk melihat discriminant validity adalah dengan melihat nilai square root of average variance extracted (AVE). Nilai yang disarankan adalah di atas 0,5 . Berikut adalah nilai AVE dalam penelitian ini:

\begin{tabular}{|c|c|}
\hline \multicolumn{2}{|c|}{ Tabel 5. Average Variance Extracted (AVE) } \\
\hline & Average Variance Extreacted (AVE) \\
\hline Faktor Eksternal $\left(X_{1}\right)$ & 0.567 \\
\hline Faktor Internal $\left(X_{2}\right)$ & 0.507 \\
\hline Faktor Kewirausahaan $\left(X_{3}\right)$ & 0.548 \\
\hline Kinerja UMKM $(Y)$ & 0.518 \\
\hline
\end{tabular}

Tabel 5 di atas menunjukkan nilai AVE di atas 0,50 untuk semua konstruk yang terdapat pada model penelitian. Nilai terendah AVE adalah sebesar 0,507 pada konstruk Faktor Internal $\left(\mathrm{X}_{2}\right)$. Dengan demikian dapat disimpulkan bahwa konstruk faktor internal, faktor ekstenal, faktor kewirausahaan, dan kinerja UMKM dinyatakan valid.

\section{Uji Reliabilitas PLS}

Hasil output software Smart-PLS 3.0 didapatkan nilai Composite Reliability dan Cronbach's Alpha masing-masing variabel konstruk sebagai berikut:

\begin{tabular}{|c|c|}
\hline \multicolumn{2}{|c|}{ Tabel 6. Composite Reliability } \\
\hline & Composite Reliability \\
\hline Faktor Eksternal $\left(X_{1}\right)$ & 0.899 \\
\hline Faktor Internal $\left(X_{2}\right)$ & 0.859 \\
\hline Faktor Kewirausahaan $\left(X_{3}\right)$ & 0.905 \\
\hline Kinerja UMKM (Y) & 0.842 \\
\hline
\end{tabular}

Tabel 6 di atas menunjukkan bahwa nilai composite reliability untuk semua konstruk adalah di atas 0,7 yang menunjukkan bahwa semua konstruk pada model yang diestimasi memenuhi kriteria. Nilai composite reliability yang terendah adalah sebesar 0,842 pada konstruk Kinerja UMKM. Hal ini menunjukkan bahwa semua variabel memiliki reliabilitas yang baik terhadap masing-masing konstruknya.

Uji reliabilitas juga bisa diperkuat dengan Cronbach's Alpha di mana output memberikan hasil sebagai berikut:

\begin{tabular}{|c|c|}
\hline \multicolumn{2}{|c|}{ Tabel 7. Cronbach's Alpha } \\
\hline & Cronbach's Alpha \\
\hline Faktor Eksternal $\left(X_{1}\right)$ & 0.869 \\
\hline Faktor Internal $\left(X_{2}\right)$ & 0.807 \\
\hline Faktor Kewirausahaan $\left(X_{3}\right)$ & 0.894 \\
\hline Kinerja UMKM $(Y)$ & 0.767 \\
\hline
\end{tabular}

Nilai yang disarankan adalah di atas 0,6 dan pada tabel 7 di atas menunjukkan bahwa nilai Cronbach's Alpha untuk semua kontruk berada di atas 0,6. Nilai Cronbach's Alpha yang terendah adalah sebesar 0,767 pada kinerja UMKM. Hal ini menunjukkan bahwa semua variabel memiliki reliabilitas yang baik terhadap masing-masing konstruknya.

\section{Model Struktural (Inner Model)}

Pengujian terhadap model ini dilakukan dengan melihat nilai $R$-Square, QSquare, nilai koefisien analisis jalur (Path Coefficients), dan nilai $t$-statistic. 


\section{R Square}

Di mana R Square digunakan untuk variabel dependen. Hasil output software Smart-PLS 3.0 sebagai berikut:

\begin{tabular}{|c|c|c|}
\hline \multicolumn{3}{|c|}{ Tabel 8. Nilai R Square dan R Square Adjusted } \\
\hline & R Square & R Square Adjusted \\
\hline Kinerja UMKM (Y) & 0.506 & 0.491 \\
\hline
\end{tabular}

Berdasarkan tabel 8 di atas, dapat diketahui bahwa besarnya R Square ( $\mathrm{R}^{2}$ ) Kinerja UMKM adalah sebesar 0,506. Dengan demikian menunjukkan pengaruh faktor internal, faktor eksternal, dan faktor kewirausahaan memberikan kontribusi pengaruh terhadap kinerja UMKM sebesar 50,6\%, sedangkan sisanya sebesar $49,4 \%$ dipengaruhi oleh faktor lain.

\section{Q Square}

Q-Square predictive relevance untuk model struktural, mengukur seberapa baik nilai observasi dihasilkan oleh model dan juga estimasi parameternya. Nilai Q-square $>0$ menunjukkan model memiliki predictive relevance. Sebaliknya jika nilai $Q$-Square $\leq 0$ menunjukkan model kurang memiliki predictive relevance. Perhitungan Q-Square dilakukan dengan rumus:

\section{$\mathrm{Q} 2=1-\left(1-\mathrm{R}_{1}{ }^{2}\right)\left(1-\mathrm{R}_{2}{ }^{2}\right) \ldots\left(1-\mathrm{R}_{\mathrm{p}}{ }^{2}\right)$}

Di mana $\mathrm{R}_{1}^{2}, \mathrm{R}_{2}^{2} \ldots \mathrm{R}_{\mathrm{p}}^{2}$ adalah $\mathrm{R}$-Square variabel endogen dalam model persamaan. Besaran $\mathrm{Q}^{2}$ memiliki nilai dengan rentang $0<\mathrm{Q}^{2}$ $<1$, di mana semakin mendekati 1 berarti model semakin baik.

$$
\begin{aligned}
\mathrm{Q}^{2} & =1-\left(1-\mathrm{R}_{1}^{2}\right) \\
& =1-(1-0,506) \\
& =1-(0,494) \\
& =1-0,494 \\
& =0,506
\end{aligned}
$$

Terlihat bahwa hasil $\mathrm{Q}^{2}$ di atas adalah sebesar 0,506. Hasil ini sesuai dengan ketentuan bahwa: Besaran $\mathrm{Q}^{2}$ memiliki nilai dengan rentang $0<\mathrm{Q}^{2}$ $<1$, di mana semakin mendekati 1 berarti model dinyatakan baik. Jadi $0<0,506<1$, di mana semakin mendekati 1 berarti model dinyatakan baik.

\section{Koefisien Jalur (Path Coefficients)}

Berdasarkan hasil pengolahan data unuk model struktural bagian koefisien analisis jalur (Path Coefficients), diperoleh hasil sebagai berikut:

\begin{tabular}{|l|c|c|c|}
\hline \multicolumn{4}{|c|}{ Tabel 9. Hasil Nilai Koefisien Analisis Jalur } \\
\hline & $\begin{array}{c}\text { Original } \\
\text { Sample (0) }\end{array}$ & $\begin{array}{c}\text { T Statistics } \\
\text { (I0/STERRI) }\end{array}$ & P Values \\
\hline $\begin{array}{l}\text { Faktor Eksternal -> Kinerja } \\
\text { UMKM }\end{array}$ & 0.365 & 4.477 & 0.000 \\
\hline Faktor Internal -> Kinerja UMKM & 0.350 & 4.168 & 0.000 \\
\hline $\begin{array}{l}\text { Faktor Kewirausahaan -> } \\
\text { Kinerja UMKM }\end{array}$ & 0.231 & 3.562 & 0.000 \\
\hline
\end{tabular}

Berdasarkan tabel 9 di atas terlihat pada kolom Original Sample (O) bahwa hasil nilai koefisien analisis jalur, dapat disimpulkan semua pengujian antar variabel faktor eksternal terhadap kinerja UMKM menunjukkan hasil 0.365, kriteria faktor internal terhadap kinerja UMKM menunjukan hasil 0.350 , kriteria faktor kewirausahaan terhadap kinerja UMKM menunjukan hasil 0.231. Dengan demikian dapat disimpulkan bahwa semua menunjukkan pengaruh positif terhadap kinerja UMKM.

\section{Uji t-Statistik}

Uji t atau uji parsial digunakan untuk mengetahui ada atau tidaknya pengaruh signifikan antara faktor eksternal, faktor internal, dan faktor kewirausahaan terhadap kinerja UMKM.

Diketahui $\mathrm{t}_{\text {tabel }}=1.986$ yang diperoleh dari rumus $\mathrm{df}=\mathrm{N}-\mathrm{K}$ atau $\mathrm{df}=50-5=45$, kemudian dihubungkan dengan derajat kepercayaan 5\% atau 0,05. Berdasarkan hasil pengolahan data untuk uji signifikansi (Uji t) pada Tabel 9, dapat dilihat bahwa hasil pengujian variabel faktor eksternal terhadap kinerja UMKM menunjukkan nilai $\mathrm{t}_{\text {hitung }} 4,477>$ ttabel 1,986 dan nilai Signifikan sebesar $0,000<0,05$ ini menunjukkan bahwa faktor eksternal berpengaruh signifikan terhadap kinerja UMKM.

Selanjutnya berdasarkan tabel di atas dapat dilihat bahwa hasil pengujian variabel faktor internal terhadap kinerja UMKM menunjukkan nilai $\mathrm{t}_{\text {hitung }} 4,168>\mathrm{t}_{\text {tabel }} 1,986$ dan nilai Signifikan sebesar $0,000<0,05$ ini menunjukkan bahwa faktor internal berpengaruh signifikan terhadap kinerja UMKM.

Kemudian berdasarkan tabel di atas dapat dilihat bahwa hasil pengujian variabel faktor 
kewirausahaan terhadap kinerja UMKM menunjukkan nilai $\mathrm{t}_{\text {hitung }} 3,562>\mathrm{t}_{\text {tabel }} 1,986$ dan nilai Signifikan sebesar 0,000 $<0,05$ ini menunjukkan bahwa faktor kewirausahaan berpengaruh signifikan terhadap kinerja UMKM.

Berikut rangkuman hasil perhitungan dan pengujian koefisien jalur berdasarkan Tabel 9, sebagai berikut:

a. Koefisiensi jalur variabel faktor eksternal terhadap kinerja UMKM sebesar 4,477.

b. Koefisiensi jalur variabel faktor internal terhadap kinerja UMKM sebesar 4.168.

c. Koefisiensi jalur variabel faktor kewirausahaan terhadap kinerja UMKM sebesar 3.562.

Berdasarkan nilai $t_{\text {hitung }}$, diperoleh hasil bahwa faktor eksternal merupakan faktor yang paling berpengaruh dan signifikan terhadap kinerja UMKM.

\section{Pembahasan}

Hasil dari penelitian ini yaitu terdapat pengaruh yang signifikan antara faktor eksternal, terhadap kinerja UMKM. Adanya kebijakan pemerintah untuk mendukung kegiatan UMKM, seperti pembinaan pengembangan usaha, penyediaan informasi untuk membantu perkembangan usaha, dan memberi kemudahan izin untuk pelaku usaha. Aspek sosial ekonomi seperti pendapatan masyarakat, memperhatikan kebutuhan budaya, dan karakteristik konsumen dapat meningkatkan penjualan. Aspek peranan lembaga terkait dalam hal ini lmbaga keuangan yang membantu modal UMKM sehingga dapat meningkatkan kinerja UMKM. Selain itu, juga ada pelatihan manajemen, keterampilan produk, dan pemasaran yang dapat membantu mengembangkan usaha serta adanya pemantauan atau monitoring yang dilakukan pemerintah terhadap perkembangan usaha UMKM.

Hasil penelitian ini juga menggambarkan adanya pengaruh dan signifikan dari faktor internal terhadap kinerja UMKM. Aspek Sumber Daya Manusia melakukan penyeleksian tenaga kerja yang sudah memiliki pengalaman bekerja, memberikan pelatihan, dan pembagian tugas sesuai keahlian masing-masing. Aspek keuangan yaitu memperhatikan sumber modal yang akan digunakan untuk kegiatan usaha dan kemampuan perusahaan untuk mendapatkan laba. Aspek produksi dan operasional yaitu dengan penggunaan bahan baku yang dimanfaatkan secara maksimal untuk menciptakan variasi produk yang berkualitas. Aspek pemasaran dalam menjalankan kegiatan pemasaran agar tidak kalah saing maka harga jual dan kualitas produk harus kompetitif, lalu menjalankan kegiatan promosi melalui media seperti brosur, pamphlet, atau media social untuk memperkenalkan produk, memperluas pasar, dan meningkatkan penjualan.

Penelitian ini juga menunjukkan adanya pengaruh dan signifikan dari aspek kewirausahaan terhadap kinerja UMKM. Seorang wirausaha harus memiliki sifat percaya diri, memiliki optimisme untuk mencapai keberhasilan, tidak mudah menyerah, mau bekerja keras, tidak takut gagal, bisa bekerja sama dengan orang lain, dapat menerima pendapat orang lain, dan tidak cepat puas dengan sebuah keberhasilan. Berdasarkan pengolahan data untuk model struktural bagian koefisien analisis jalur (Path Coefficients), dapat disimpulkan bahwa semua variabel menunjukkan pengaruh signifikan terhadap kinerja UMKM.

Berdasarkan hasil perhitungan, besarnya $R$ Square $\left(\mathrm{R}^{2}\right)$, kinerja UMKM adalah sebesar 0,506. Artinya adalah faktor internal, faktor eksternal, dan faktor kewirausahaan memberikan kontribusi pengaruh sebesar 50,6\% terhadap kinerja UMKM. Sedangkan sisanya sebesar 49,4\% dipengaruhi oleh faktor lain. Hasil penelitian ini sesuai dengan teori yang dinyatakan oleh Wang dan Wong (2004), Said (2004), serta Jauch dan Glueck (2000), yang menyatakan bahwa faktor internal dan faktor eksternal adalah faktor-faktor yang mempengaruhi kinerja UMKM.

\section{SIMPULAN}

Variabel eksternal yaitu aspek kebijakan pemerintah, aspek social ekonomi, dan aspek peran lembaga terkait berpengaruh dan signifikan terhadap kinerja UMKM. Variabel internal yaitu aspek sumber daya manusia, aspek produksi dan operasional, serta aspek pemasaran memiliki pengaruh dan signifikan terhadap kinerja UMKM. Variabel kewirausahaan berpengaruh 
terhadap kinerja UMKM.

Berdasarkan hasil penelitian yang telah dilakukan maka sebaiknya para pelaku UMKM di Kecamatan Bogor Utara lebih meningkatkan lagi pengetahuan dan pemahaman mengenai faktor internal, faktor eksternal, dan faktor kewirausahaan agar dapat meningkatkan kinerja perusahaan. UMKM juga sebaiknya terus-menerus menjalin hubungan dengan stakeholder, baik itu mendapat jaringan baru maupun mempererat jaringan yang telah terjalan sehingga terbentuk pertukaran informasi yang saling menguntungkan.

\section{PENGHARGAAN}

Kami mengucapkan terima kasih kepada pihak-pihak yang telah mendukung kami dalam penyusunan artikel ini, khususnya kepada:

1. Pemilik UMKM Fashion dan Kuliner di Kecamatan Bogor Utara.

2. Civitas Akademika Fakultas Ekonomi \& Bisnis UPN “Veteran” Jakarta.

3. Seluruh pihak yang telah mendukung kami yang tidak bisa kami sebutkan satu per satu.

\section{DAFTAR PUSTAKA}

Af'ida, Syakina Noor. (2017). Faktor-Faktor yang Mempengaruhi Kinerja Usaha Mikro, Kecil dan Menengah (UMKM) Studi Kasus Industri Pakaian Jadi di Kabupaten Kudus. FEB Universitas Muhammadiyah Yogyakarta.

Alma, Bukhari. (2013). Kewirausahaan. Bandung: Alfabeta.

Armstrong, Gary., \& Kotler, Philip. (2015). Dasar-dasar Pemasaran Jilid I, Alih Bahasa Alexander Sindoro dan Benyamin Molan. Jakarta: Prenhalindo.

Basrowi. (2011). Kewirausahaan Untuk Perguruan Tinggi. Bogor: Ghalia Indonesia.

Cipta, Suidarta Kirya. (2014). Analisis Faktorfaktor Yang Mempengaruhi Kinerja Usaha Mikro Kecil Menengah Kabupaten Bangli. Jurnal Manajemen Volume 2 Tahun 2014.

Fajar, Mukti. (2016). Usaha Mikro Menengah (UMKM) di Indonesia. Yogyakarta: Pustaka Pelajar.
Hanum, Ayu Noviani., Sinarasri, Andwiani. (2020). Analisis Faktor-Faktor Yang Mempengaruhi Adopsi E Commerce Dan Pengaruhnya Terhadap Kinerja Umkm (Studi Kasus Umkm Di Wilayah Kota Semarang). Jurnal Media Akuntansi Universitas Muhammadiyah Semarang Vol.7 No.1 E-ISSN: 2580-9482. P-ISSN: 2087-2836.

Hati, S.W., \& Irawati, Rusda. (2017). FaktorFaktor yang Mempengaruhi Kinerja Usaha Mikro Kecil Menengah (UMKM) di Kota Batam. Seminar Nasional Applied Business and Engineering Conference 2017, Pangkalpinang.

Husein, Reza. (2016). Faktor-Faktor Yang Mempengaruhi Kinerja Usaha Mikro, Kecil, Menengah Di Kabupaten Sleman. Skripsi FE UMY.

Kotler, Philip., \& Keller, Kevin Lane. (2016). Marketing Management, 15th Edition. London: Pearson Education, Inc.

Krisdanti, Gadiza., \& Rodhiyah. (2016). Analisis Faktor-Faktor Yang Mempengaruhi Kinerja UKM Pada Sektor Industri Pengolahan Makanan Di Kota Semarang. Jurnal Ilmu Administrasi Bisnis Vol.5 No.4 Tahun 2016. Hlm. 60 - 71.

Kristiningsih., \& Trimarjono, Adrianto. (2014). Analisis Faktor-Faktor yang Mempengaruhi Perkembangan Usaha Kecil Menengah (Studi Kasus Pada UKM di Wilayah Surabaya). The 7th NCFB and Doctoral Colloquium 2014. Fakultas Bisnis dan Pascasarjana UKWMS.

Purwaningsih, R., \& Kusuma, P. D. (2015). Analisis Faktor-Faktor yang Kinerja mempengaruhi UKM dengan Metode Structural Equation Modelling (Studi Kasus UKM Berbasis Industri kreatif Kota Semarang). Prosiding SNST ke-6 Tahun 2015. ISBN 978-602-99334-4-4. Fakultas Teknik Universitas Wahid Hasyim Semarang.

Ratnawati, Andalan Tri., \& Hikmah. (2020). Faktor-faktor yang Mempengaruhi Kinerja UKM (Studi Kasus UKM di Kabupaten dan Kota Semarang). Semarang: Serat Acitya Jurnal Ilmiah UNTAG Semarang Vol.2 No.1. 
Suparyanto, R.W.(2013). Kewirausahaan: Konsep Dan Realita Pada Usaha Kecil. Bandung : Alfabeta.

Sentiago, B. Hidayatullah, A.(2019). Analisis Faktor Eksternal Terhadap Faktor Internal dan Dampaknya Terhadap Kinerja UKM Daerah Istimewa Yogyakarta. Jurnal Manajemen dan Keuangan Vol.8 No.2 2019. E-ISSN: 2615-1316. P-ISSN: 2252-844X.

Siagian, M., Kurniawan, P. H., \& Hikmah. (2019). Analisis Faktor Eksternal dan Internal Terhadap Kinerja UMKM di Kota Batam. Jurnal Ekonomi \& Ekonomi Syariah Vol 2 No.2 Juni 2019. E-ISSN: 25993410. P-ISSN: 2614-3259.

Subroto, S., et al. (2016). Analisis Faktor-Faktor Yang Mempengaruhi Kinerja Usaha Mikro Kecil Dan Menengah (UMKM) Kabupaten Brebes. Prosiding Seminar Nasional Penelitian dan PKM Sosial, Ekonomi dan Humaniora. ISSN 2089-3590, EISSN 23032472 | Vol 6, No.1, Th, 2016.
Sudaryanto, R.(2011).Strategi Pemberdayaan

UMKM Menghadapi Pasar Bebas ASEAN.Yogyakarta: Kedaulatan Rakyat.

Sudiarta, I. P. L. Eka., et al. (2014).Analisis

Faktor-Faktor yang Mempengaruhi Kinerja Usaha Mikro Kecil dan Menengah (UMKM) di Kabupaten Bangli. E-Journal Bisma Universitas Pendidikan Ganesha Jurusan Manajemen Vol. 2 Tahun 2014.

Sugiyono. (2010). Metode Penelitian Kuantitatif Kualitatif dan R\&D. Bandung: PT Remaja Rosdakarya.

Sumodiningrat, G., \& Wulandari, A. (2015). Menuju Ekonomi Berdikari Pemberdayaan UMKM Dengan Konsep Opop-Ovop-Ovoc. Yogyakarta: Media Pressindo.

Wilantara, R. F., \& Susilawati. (2016). Strategi Dan Kebijakan Pengembangan UMKM. Bandung: Refika Adita. 